\title{
Pengaruh Model Problem Posing dengan Context-Rich Problem terhadap Kemampuan Berpikir Divergen dan Konvergen Siswa
}

\author{
Husnul Hatimah, Asmawati, Maeni, *Yusran Khery, Khaeruman \\ Program Studi Pendidikan Kimia, FSTT, Universitas Pendidikan Mandalika, Jl. Pemuda No. \\ 59A, Mataram 83125, Indonesia
}

*Email Korespondensi: yusrankhery@gmail.com

\begin{abstract}
Penelitian ini bertujuan untuk mengetahui pengaruh model pembelajaran Problem Posing dengan Context-Rich Problem terhadap kemampuan berpikir divergen dan kemampuan berpikir konvergen siswa. Penelitian ini merupakan penelitian eksperimen semu (quasy eksperimental) dengan rancangan penelitian posttest-only control group design. Sampel penelitian ini adalah 85 siswa kelas X SMAN 7 Mataram yang dipilih menggunakan teknik purposive sampling yang terbagi dalam 3 kelompok. Kelompok eksperimen I terdiri dari 26 siswa dibelajarkan dengan model pembelajaran Problem Posing dengan Context-Rich Problem, kelompok eksperimen II terdiri dari 29 siswa dibelajarkan dengan model Problem Posing, sedangkan kelompok kontrol terdiri dari 30 siswa dibelajarkan dengan model konvensional dengan Context-Rich Problem. Data dikumpulkan menggunakan lembar observasi keterlaksanaan pembelajaran dan tes kemampuan berpikir divergen dan konvergen. Teknik analisis data menggunakan uji varian dua jalur (two way ANOVA). Hasil penelitian menunjukan bahwa (1) penggunaan model pembelajaran Problem Posing dengan Context-Rich Problem berpengaruh $\left(F_{\text {hitung }}=4,128>F_{\text {tabel }}=3,26\right)$ terhadap kemampuan berpikir divergen siswa; (2) skor rata-rata kelompok eksperimen I (mean= 55,38) lebih tinggi dari pada kelompok eksperimen II (mean $=40,91$ ) dan kelompok kontrol (mean=42,23); (3) penggunaan model pembelajaran Problem Posing dengan Context-Rich Problem tidak berpengaruh ( $F_{\text {hitung }}=0,449<F_{\text {tabel }}=3,26$ ) terhadap kemampuan berpikir konvergen siswa; (4) skor rata-rata kelompok eksperimen I (mean $=34,5)$ lebih tinggi dari pada kelompok eksperimen II (mean $=33,25)$ dan kelompok kontrol (mean $=24,99)$. Penelitian ini menyimpulkan bahwa model pembelajaran Problem Posing dengan Context-Rich Problem berpengaruh terhadap kemampuan berpikir divergen, namun tidak berpengaruh signifikan terhadap kemampuan berpikir konvergen siswa.
\end{abstract}

Keywords: Problem Posing; Context-Rich Problem; Berpikir Divergen; Berpikir Konvergen

\section{The Effect of Problem Posing Model with Context-Rich Problem toward Students' Divergent and Convergent Thinking Ability}

Abstract

This study aims to determine the effect of the Problem Posing learning model with Context-Rich Problems on students' divergent thinking and convergent thinking abilities. This research is a quasi-experimental research with a posttest-only control group design. The sample of this study was 85 students of class X SMAN 7 Mataram who were selected using a purposive sampling technique which was divided into 3 groups. The experimental group I consisted of 26 students taught with the Problem Posing learning model with Context-Rich Problems, the experimental group II consisted of 29 students taught with the Problem Posing model, while the control group consisted of 30 students taught using the conventional model with the Context-Rich Problem. Data were collected using observation sheets on the implementation of learning and divergent and convergent thinking skills tests. The data analysis technique used a two-way ANOVA test. The results showed that (1) the use of the Problem Posing learning model with Context-Rich Problem had an effect $\left(F_{\text {count }}=4.128>F_{\text {table }}=3.26\right)$ on students' divergent thinking abilities; (2) the average score of the experimental group I (mean= 55.38) was higher than that of the experimental group II (mean= 40.91) and the control group (mean=42.23); (3) the use of Problem Posing learning model with Context-Rich Problem has no effect $\left(F_{\text {count }}=0.449<F_{\text {table }}=3.26\right)$ on students' convergent thinking ability; (4) the average score of the experimental group I (mean=34.5) was higher than the experimental group II (mean=33.25) and the control group (mean=24.99). This study concludes that the Problem Posing learning model with Context-Rich Problems has an effect on divergent thinking skills, but has no significant effect on students' convergent thinking abilities.

Keywords: Problem Posing; Context-Rich Problem; Divergent Thinking; Convergent Thinking

How to Cite: Hatimah, H., Asmawati, A., Maeni, M., Khery, Y., \& Khaeruman, K. (2021). Pengaruh Model Problem Posing dengan Context-Rich Problem terhadap Kemampuan Berpikir Divergen dan Konvergen Siswa. Empiricism Journal, 2(2), 53-62. https://doi.org/10.36312/ej.v2i2.586 


\section{PENDAHULUAN}

IImu kimia adalah cabang ilmu pengetahuan alam yang mempelajari tentang struktur materi, sifat-sifat materi, perubahan suatu materi menjadi materi lain, serta energi yang menyertai perubahan materi. Salah satu karakteristik ilmu kimia adalah sebagian besar konsep-konsepnya bersifat abstrak. Sifatnya yang abstrak menyebabkan kimia cenderung menjadi pelajaran yang sulit bagi kebanyakan siswa (Indrayani, 2013). Kesulitan siswa dalam mempelajari ilmu kimia dapat bersumber pada kesulitan dalam memahami istilah kimia, kesulitan ini timbul karena kebanyakan siswa hanya menghafal istilah dan tidak memahami dengan benar maksud dari istilah yang juga digunakan dalam pengajaran kimia, siswa juga kurang memahami rumusan perhitungan kimia (Suryati et al., 2017).

Materi hidrokarbon merupakan materi yang berupa konsep-konsep dan teori serta faktafakta. Agar dapat memahami suatu konsep dengan utuh, kita harus mengenal konsep tersebut baik dari tingkat makroskopis maupun mikroskopisnya (Indrayani, 2013). Menurut Eristya dan Aznam (2019), untuk memahami materi kimia dibutuhkan pemahaman konsep yang kuat dan bersifat komprehensif. Selain berisi konsep-konsep, materi ini memuat hal-hal yang sifatnya mendasar dalam ilmu kimia, seperti bagaimana menuliskan rumus kimia dan bagaimana memberi nama pada senyawa kimia. Materi hidrokarbon juga memberikan pengetahuan tentang nama senyawa-senyawa kimia yang sangat asing bagi siswa karena lazim digunakan dalam kehidupan sehari-hari (Widowati, 2008). Oleh karena itu ketelitian, keterampilan, dan kemampuan dalam berpikir sangat dibutuhkan dalam menguasai materi.

Menurut Khery et al. (2013) proses menuju pemahaman dan penguasaan materi kimia membutuhkan proses berpikir yang divergen dan konvergen. Akan tetapi ada siswa yang memiliki kecenderungan untuk divergen atau lebih cenderung berpikir konvergen. Berpikir divergen bersifat generatif, jawabannya lebih bervariasi sehingga secara mental mereka lebih berani mengambil resiko karena divergen melihat dari berbagai segi atau sudut pandang dari jawaban soal. Berpikir konvergen yaitu bersifat selektif, jawabannya mengarah kepada satu jawaban yang benar sehingga secara mental mereka tidak berani mengambil resiko. Siswa konvergen cenderung mengikuti prosedur sedangkan siswa divergen lebih berani tidak mengikuti prosedur yang ada melainkan lebih berani mencoba ide-ide baru dari sudut pandang yang berbeda. Dalam materi hidrokarbon, berpikir divergen muncul ketika siswa diminta membuat nama suatu struktur senyawa hidrokarbon bisa memiliki lebih dari satu nama atau ketika membuat berbagai isomer yang mungkin rumus molekul hidrokabon. Hal ini juga pada berpikir konvergen muncul ketika siswa diminta menentukan jenis atau struktur senyawa hidrokarbon berdasarkan reaksinya.

Berdasarkan hasil observasi awal pada pembelajaran kimia kelas X SMAN 7 Mataram. Terdapat beberapa permasalahan diantaranya masih banyak siswa yang menganggap pelajaran kimia adalah pelajaran yang sulit dipahami. Siswa kesulitan dalam menggambarkan struktur senyawa hidrokarbon, menentukan nama untuk struktur yang dianggap rumit, isomer dan konsep-konsep lainnya. Siswa hanya dituntut untuk menyelesaikan soal tes tanpa melalui proses berpikir yang menuntun siswa untuk menguasai konsep berkaitan dengan materi hidrokarbon yang dipelajari. Perbedaan kecenderungan berpikir siswa dan rendahnya hasil belajar siswa perlu mendapat perhatian dari pendidik agar dalam proses pembelajaran yang terjadi dapat terarah sesuai dengan pola pikir siswa sehingga tujuan pembelajaran dapat tercapai. Hasil penelitian Hidayatulloh et al. (2020) juga menyatakan bahwa siswa seringkali kesulitan dalam pembelajaran kimia dan teridentifikasi literasi kimia yang rendah. Namun penelitian tersebut berbeda dengan penelitian ini karena berpusat pada pengembangan buku ajar materi prinsip reaksi untuk membelajaran pemecahan masalah kimia.

Salah satu strategi yang dapat digunakan dalam mengembangkan kemampuan berpikir dan meningkatkan kreaktivitas siswa adalah model Problem Posing dengan Context-Rich Problem. Menurut Suryani et al. (2015) model pembelajaran pengajuan masalah (problem posing) merupakan salah satu pembelajaran yang menuntut para siswa untuk mengajukan soal dan memecahkan sendiri soal yang diajukannya. Latar belakang masalah dapat berdasar topik yang luas, soal yang sudah dikerjakan atau informasi tertentu yang diberikan kepada siswa. Jadi dalam pembelajaran problem posing siswa dilatih untuk bertanya. Padahal, bertanya merupakan pangkal semua kreasi. Orang yang memiliki kemampuan berkreasi dikatakan memiliki sikap kreatif. Selain itu dengan pengajuan soal, siswa diberi kesempatan aktif secara mental, fisik, dan sosial serta memberikan kesempatan kepada siswa untuk 
menyelidiki dan membuat jawaban serta dapat memberikan kepuasan tersendiri bagi siswa jika soal yang dibuat tidak mampu diselesaikan oleh kelompok lain.

Penggunaan model pembelajaran Problem Posing bertujuan untuk memaksimalkan proses dan aktifitas siswa dan dapat mendorong kemampuan berpikir. Pembelajaran yang dapat mendorong kemampuan berpikir harus mencakup pada tugas berpikir divergen dan konvergen. Tugas berpikir divergen dan konvergen dalam kimia adalah tugas yang diberikan guru kepada siswa yang dapat menimbulkan proses berpikir yang menghasilkan ide secara simultan. Pada prosesnya, munculnya suatu ide, dapat memicu timbulnya ide yang lain sehingga siswa dapat mengembangkan cara pemikiran mereka dalam memahami konsepkonsep hidrokarbon selama proses pembelajaran (Khery \& Supriani, 2014).

Model pembelajaran problem posing dapat diterapkan dengan menyajikan Context-Rich Problem (soal-soal yang diperkaya dengan konteks-konteks) (Khery \& Khaeruman, 2016). Context-Rich Problem (CRP) mencoba membawa siswa memasuki permasalahan yang bisa ditemui didunia nyata. Context-Rich Problem dirancang untuk mendorong siswa menggunakan strategi pemecahan masalah yang terorganisir dan logis. Dengan demikian siswa terdorong mempertimbangkan konsep-konsep pada konteks objek nyata. Semakin akrab konteks dimana permasalahan itu dihadirkan dan semakin dekat permasalahan tersebut dengan pengalaman keseharian siswa, maka siswa akan semakin menyukai untuk membuat hubungan-hubungan yang diperlukan dan tiba pada penafsiran yang tepat terhadap permasalahan (Khery \& Khaeruman, 2016).

Model pembelajaran Problem Posing yang diterapkan dengan Contex-Rich Problem dalam meningkatkan kemampan berpikir divergen dan konvergen siswa yaitu soal-soal yang dibuat lebih banyak, soal-soal sesuai dengan situasi dalam dunia nyata siswa, dan soal yang dibuat lebih terorganisir. Hal ini berbeda dengan model Problem Posing tanpa Context-Rich Problem karena dalam membuat soal tidak terorganisir sehingga siswa akan lebih sulit dalam membuat dan memecahkan soal, karena dalam meningkatkan kemampuan berpikir siswa perlu adanya pengalaman dunia nyata siswa sehingga akan lebih mudah bagi siswa dalam menyelesaikan suatu soal. Berdasarkan uraian tersebut maka penelitian ini bertujuan untuk mengetahui pengaruh model pembelajaran Problem Posing dengan Context-Rich Problem terhadap kemampuan berpikir divergen siswa dan konvergen siswa.

\section{METODE}

Populasi penelitian ini yakni 170 siswa kelas X SMAN 7 Mataram. Subjek penelitian kelas eksperimen terdiri dari dua kelas, dimana kelas eksperimen I di belajarkan dengan model pembelajaran Problem Posing dengan Context-Rich Problem, kelas eksperimen II dibelajarkan dengan Problem Posing saja, dan kelas control dibelajarkan dengan model konvensional dengan Context-Rich Problem. Pengelompokkan siswa dilakukan dengan metode kategorisasi kemampuan awal tinggi, sedang dan rendah berdasarkan nilai kemampuan awal siswa. Variabel dalam penelitian ini yakni model pembelajaran Problem Posing dengan ContextRich Problem sebagai variable bebas. Varibel terikatnya yakni kemampuan berpikir divergen dan konvergen.

Penelitian ini dilaksanakan dengan jenis rancangan eksperimental semu, Desain ini memiliki kelompok kontrol akan tetapi tidak sepenuhnya dapat mengontrol variabel-variabel lain yang dapat mempengaruhi pelaksanaan dan hasil eksperimen (Arikunto, 2013). Dalam penelitian ini digunakan rancangan Postest Only-Control Group Design sebagaimana disajikan dalam Tabel 1.

Tabel 1. Post-tes Only Control Design (Sugiyono, 2010)

\begin{tabular}{ccc}
\hline Kelas & Perlakuan & Post-test \\
\hline Eksperimen I (E1) & Problem posing-CRP $\left(\mathrm{X}_{1}\right)$ & $\mathrm{KBD}_{1}, \mathrm{KBK}_{1}$ \\
Eksperimen II (E2) & Problem Posing $\left(\mathrm{X}_{2}\right)$ & $\mathrm{KBD}_{2}, \mathrm{KBK}_{2}$ \\
Kontrol (K) & Konvensional dengan $\boldsymbol{C R P}(\mathrm{Y})$ & $\mathrm{KBD}_{3}, \mathrm{KBK}_{3}$
\end{tabular}

Keterangan:

E1 = Perlakuan menggunakan model Problem Posing dengan CRP

E2 = Perlakuan menggunakan model Problem Posing saja

$\mathrm{K}=$ Perlakuan menggunakan model konvesional dengan CRP 
$\mathrm{KBD}_{1}=$ Kemampuan berpikir divergen setelah diberi perlakuan kelas eksperimen I

$\mathrm{KBK}_{1}=$ Kemampuan berpikir konvergen setelah diberi perlakuan kelas eksperimen I

$\mathrm{KBD}_{2}=$ Kemampuan berpikir divergen setelah diberi perlakuan kelas eksperimen II

$\mathrm{KBK}_{2}=$ Kemampuan berpikir konvergen setelah diberi perlakuan kelas esperimen II

$\mathrm{KBD}_{3}=$ Kemampuan berpikir divergen setelah diberi perlakuan kelas kontrol

$\mathrm{KBK}_{3}=$ Kemampuan berpikir konvergen setelah diberi perlakuan kelas kontrol

Beberapa instrumen yang digunakan dalam penelitian ini yaitu: (1) instrument perlakuan yang meliputi silabus, RPP dan LKS; (2) isntrumen evaluasi yang meliputi lembar keterlaksanaan RPP, tes kemampuan berpikir divergen dan konvergen yang berupa soal essay. Soal-soal tersebut divalidasi pada kelas XI Ipa. Data yang diperoleh dianalisis dengan uji statistik. Data Kemampuan Berpikir Divergen dan Konvergen dikumpulkan menggunakan tes kemampuan berpikir Divergen dan Konvergen yang dikembangkan oleh (Khery \& Supriani, 2014).

Analisis statistik yang digunakan dalam penelitian ini terdiri dari uji prasyarat dan uji hipotesis. Uji prasyarat meliputi uji normalitas dan uji hipotesis meliputi analisis varians (ANOVA). Analisis varians digunakan untuk menguji hipotesis yang berkenaan dengan perbedaan kemampuan berpikir siswa. Hasil perhitungan uji analisis varian dinyatakan dengan nilai $F$. Analisi varians yang digunakan pada penelitian ini adalah analisi varians dua jalur (two way ANOVA) dengan dengan bantuan Microsoft Office Excel for Wondows.

\section{HASIL DAN PEMBAHASAN Kemampuan Awal Siswa}

Data kemampuan awal siswa diperoleh dari nilai ulangan materi sebelum hidrokarbon yaitu materi reaksi redoks. Adapun nilai ulangan harian siswa yang didapatkan data seperti pada Tabel 2.

Tabel 2. Data Kemampuan Awal dan Ketuntasan Siswa kelas $X_{A}, X_{B} X_{E}$

\begin{tabular}{cccclc}
\hline Kelas & N & Mean & K.Awal tinggi & K.Awal Sedang & K.Awal Rendah \\
\hline$X_{A}$ & 26 & 67,43 & 8 & 16 & 2 \\
$X_{B}$ & 29 & 70,10 & 8 & 20 & 1 \\
$X_{E}$ & 30 & 59,83 & 2 & 17 & 11 \\
\hline
\end{tabular}

Pada tabel 3 dapat dilihat bahwa siswa yang memilki kemampuan awal tinggi lebih banyak dikelas eksperimen I. Maka dari itu, dapat disimpulkan bahwa kelas eksperimen I memiliki kemampuan awal yang lebih baik dari kelas eksperimen II dan kontrol.

Analisis ketuntasan belajar siswa dilakukan untuk mengetahui perbedaan siswa yang berkemampuan awal tinggi dengan siswa yang berkemampuan awal rendah baik dikelas eksperimen maupun dikelas kontrol. Kategori kemampuan awal siswa dipaparkan pada Gambar 1.

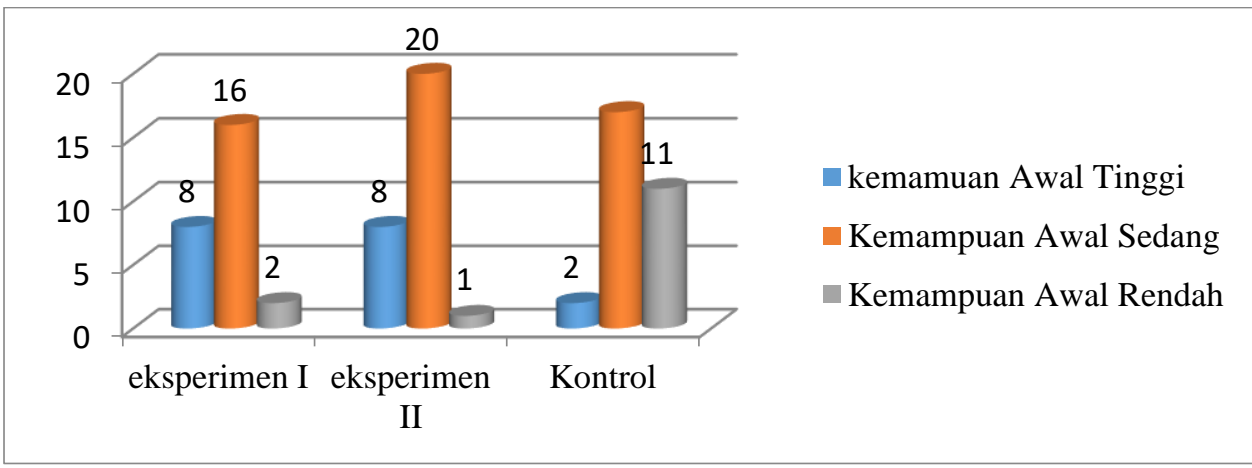

Gambar 1. Diagram Perbandingan Kemampuan Awal siswa

Pada Gambar 1 dapat dilihat bahwa kelas eksperimen I dan kelas eksperimen II memiliki siswa yang berkemampuan awal tinggi sama banyak dan kelas kontrol memiliki siswa yang berkemampuan awal tinggi lebih sedikit, untuk siswa yang berkemampuan awal sedang pada kelas eksperimen II lebih banyak dibandingkan dengan siswa yang di kelas eksperimen I dan kelas kontrol, sedangkan untuk siswa yang berkemampuan awal rendah pada kelas kontrol 
lebih banyak dari pada siswa yang berkemampuan awal rendah pada kelas eksperimen I dan kelas eksperimen II. Sehingga dapat disimpulkan bahwa siswa kelas eksperimen I pada dasarnya memiliki kemampuan awal yang lebih baik dari pada kelas eksperimen II dan kontrol.

\section{Keterlaksanaan RPP}

Observasi keterlaksanaan RPP dilakukan dengan tujuan untuk melihat sejauh mana presentasi keterlaksanaan pembelajaran yang dilakukan. Data keterlaksanaan pembelajaran ini di data oleh obsever teman sejawat. Berdasarkan analisa observasi keterlaksanaan RPP, proses belajar siswa pada kelas eksperimen dan kelas kontrol berlangsung sangat baik dapat dilihat pada Gambar 2.

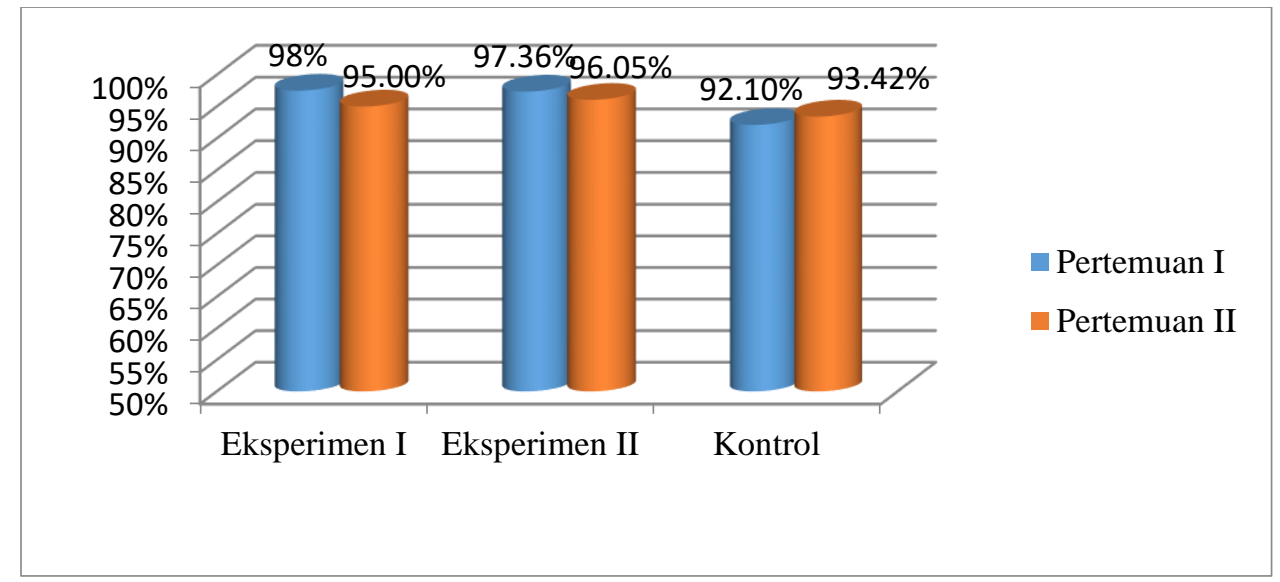

Gambar 2. Keterlaksanaan RPP

Berdasarkan Gambar 2 dapat dilihat bahwa skor ketelaksanaan RPP pada pertemuan pertama sampai pertemuan kedua pada kelas eksperimen dan kelas kontrol mengalami peningkatan dengan kategori masing-masing skor yakni sangat baik dan berada pada presentase yang hampir sama di mana semua indikator pembelajaran juga tercapai dengan baik. Hal ini menunjukkan bahwa walaupun guru menerapkan perlakuan yang berbeda pada ketiga kelas, tapi presentase keterlaksanaan semua perlakuan yang diterapkan hampir sama. Sehingga dapat disimpulkan bahwa kegiatan pembelajaran menggunakan model pembelajaran Problem Posing dengan Context-Rich Problem, Problem Posing saja dan model konvensional dengan Context-Rich Problem terlaksana dengan sangat baik. Maka dari itu dapat diyakini bahwa segala fenomena dalam kegiatan pembelajaran yang terjadi baik di kelas eksperimen dan kontrol dalam penelitian ini merupakan akibat dari perlakuan/pembelajaran yang diberikan/diterapkan.

\section{Pengaruh Model Pembelajaran Problem Posing dengan Context-Rich Problem terhadap Kemampuan Berpikir Divergen Siswa}

Deskripsi data kemampuan berpikir divergen siswa yang dibelajarkan dengan model pembelajaran Problem Posing dengan Context-Rich Problem, model Problem Posing saja dan model konvensional dengan Context-Rich Problem disajikan pada tabel 3.

Tabel 3. Deskripsi Data Kemampuan Berpikir Divergen Kelas Eksperimen I, Kelas Eksperimen II dan Kelas Kontrol

\begin{tabular}{cccc}
\hline Varian & N & Mean & Std. deviation \\
\hline Kemampuan berpikir divergen kelas eksperimen I & 26 & 55,38 & 10,24487 \\
\hline Kemampuan berpikir divergen kelas eksperimen II & 29 & 40,91 & 18,51419 \\
\hline Kemampuan berpikir divergen kelas kontrol & 30 & 42,23 & 13,79925 \\
\hline
\end{tabular}

Pada Tabel 3 dapat dilihat bahwa nilai tes kemampuan berpikir divergen siswa pada kelas eksperimen I lebih tinggi dari kelas eksperimen II dan kontrol. 
Analisis normalitas data sampel menggunakan uji statistik atau melalui bantuan program bantuan program Microsoft excel 07, sehingga diperoleh hasil pada signifikan pada kelas eksperimen I, eksperimen II, dan kontrol seperti yang dipaparkan pada Tabel 4.

Tabel 4. Uji Normalitas Data Poss-test Kemampuan Berpikir Divergen Siswa

\begin{tabular}{lccc}
\multicolumn{1}{c}{ Kelas } & $\begin{array}{c}\text { Chi Kuadrat } \\
\text { Hitung }\end{array}$ & $\begin{array}{c}\text { Taraf signifikan } \\
\mathbf{5} \%\end{array}$ & Kriteria \\
\hline Eksperimen I & 10,83 & \multirow{2}{*}{11,070} & \\
\cline { 1 - 2 } Eksperimen II & 9,97 & & Terdistribusi Normal \\
\hline Kontrol & 7,50 & & Terdistribusi Normal \\
\hline
\end{tabular}

Pada Tabel 4 di atas, untuk kelas eksperimen I diperoleh harga Chi Kuadrad hitung $=10,83$, kelas eksperimen II diperoleh Chi Kuadrat hitung 9,97, dan kelas kontrol diperoleh Chi Kuadrat hitung 7,50. Berdasarkan tabel Chi Kuadrat dapat diketahui bahwa untuk tingkat kesalahan = $5 \%$, harga Chi Kuadrad tabel $=11,070$. Maka dari itu, Chi Kuadrat hitung lebih kecil dari Chi Kuadrat tabel. Artinya data kemampuan berpikir divergen terdistribusi normal.

Uji Analisis varians digunakan untuk menguji hipotesis yang berkenaan dengan perbedaan kemampuan berpikir divergen siswa. Analisis varians yang digunakan pada penelitian ini adalah analisis varians dua jalur (two way ANOVA) dengan faktorial $(2 \times 3)$ dengan bantuan Microsoft excel, hasil uji hipotesis untuk kemampuan berpikir divergen siswa dapat dilihat pada Tabel 5.

Tabel 5. Hasil Uji Hipotesis Data Kemampuan Berpikir Divergen Siswa

\begin{tabular}{lccccc}
\hline \multicolumn{1}{c}{ Sumber variable } & Dk & $\begin{array}{c}\text { Jumlah } \\
\text { kuadrat }\end{array}$ & $\begin{array}{c}\text { Mean } \\
\text { kuadrat }\end{array}$ & Fh & $\begin{array}{c}\mathrm{Ft} \\
5 \%\end{array}$ \\
\hline $\begin{array}{l}\text { KBD kelas Eksperimen I, } \\
\text { Eksperimen II dan kontrol }\end{array}$ & $3-1=2$ & 3326,21 & 16631,1 & 4,128 & 3,2 \\
\hline $\begin{array}{l}\text { KBD berdasarkan kemampuan } \\
\text { awal }\end{array}$ & $3-1=2$ & 229,9 & 114,9 & 0.028 & \\
\hline $\begin{array}{l}\text { Interaksi (berdasarkan kelas dan } \\
\text { kemampuan awal) }\end{array}$ & $2 \times 2=4$ & 8245,99 & 4122,9 & 1,023 \\
\hline Kelas & $85-3 \times 3=$ & 306170,4 & 4028,5 & \\
\hline Total & 76 & & & & \\
\hline
\end{tabular}

Dari Tabel 5 di atas di atas diperoleh $\mathrm{F}_{\text {hitung }}=4,128$ untuk kemampuan berpikir divergen berdasarkan kelas, $F_{\text {hitung }}=0,028$ untuk kemampuan berpikir divergen berdasarkan kemampuan awal, $F_{\text {hitung }}=1,023$ untuk interaksi berdasarkan kelas dan kemampuan awal dan $F_{\text {tabel }}$ untuk $\alpha=0,05$ adalah 3,26. Dapat disimpulkan bahwa $F_{\text {hitung }}>F_{\text {tabel }}$ sehingga Ho ditolak dan $\mathrm{Ha}$ diterima. Artinya ada perbedaan kemampuan berpikir divergen siswa kelas eksperimen I, kelas eksperimen II, dan kelas kontrol pada materi hidrokarbon yang disebabkan oleh perbedaan perlakuan dalam pembelajaran. Dimana skor rata-rata kemampuan berpikir divergen kelas eksperimen I 55,38; eksperimen II 40,91; kelas kontrol 42,23.

Pada Tabel 4 siswa kelas eksperimen I memiliki skor rata-rata kemampuan berpikir divergen tinggi. Hal ini dapat dilihat dari hasil deskripsi data yang menunjukan skor rata-rata 55,38 . Kelas eksperimen II memiliki skor rata-rata kemampuan berpikir divergen yang lebih rendah dari kelas eksperimen I. Hal ini dapat dilihat dari hasil deskripsi data yang menunjukan skor rata-rata 40,91. Kelas kontrol memiliki skor rata-rata kemampuan berpikir divergen yang lebih baik dari kelas eksperimen II. hal ini dapat dilihat dari hasil deskripsi data yang menunjukan bahwa skor rata-rata kemampuan berpikir divergen yaitu 42,23.

Berdasarkan uraian diatas kemampuan berpikir divergen kelas eksperimen I dan kelas kontrol lebih baik dari pada skor kemampuan berpikir divergen kelas eksperimen II. Adanya perbedaan kemampuan berpikir siswa tersebut dilihat dari perlakuan yang diberikan pada materi hidrokarbon.

Sedangkan berdasarkan analisis data dan uji hipotesis yaitu analisis varians dua jalur (two way ANOVA) dengan factorial (2x3) dengan bantuan Microsoft excel 07, perbandingan kemampuan berpikir divergen kelas eksperimen I yang diberi perlakuan Problem Posing 
dengan CRP , kelas eksperimen II yang diberi perlakuan Problem Posing saja dan kelas kontrol yang diberi perlakuan dengan model konvensional terdapat perbedaan. Dimana hasil analisis menunjukan bahwa kelas yang berkemampuan berpikir divergen kelas eksperimen lebih baik secara signifikan dari pada kemampuan berpikir divergen kelas kontrol. Perbedaan kemampuan berpikir divergen kelas eksperimen I, kelas eksperimen II dan kelas kontrol disebabkan oleh perlakuan yang diberikan, yaitu baik yang kemampuan awal tinggi, sedang dan rendah semuanya bisa lebih baik kemampuan berpikir divergennya dalam penerapan model pembelajaran Problem Posing dengan Context-Rich Problem.

Selama proses pembelajaran yang terjadi peneliti melihat bahwa kelas eksperimen lebih aktif dari pada kelas kontrol dalam menanyakan hal-hal yang belum mereka pahami dalam mengerjakan soal baik menggunakan Problem Posing dengan CRP maupun Problem Posing saja. Hal ini dapat lihat dari model pembelajaran Problem Posing yang dimana para siswa dilatih untuk bertanya. Padahal bertanya merupakan pangkal semua kreasi. Siswa yang memiliki kesempatan berkreasi dikatakan memiliki sikap kreatif. Selain itu dengan pengajuan soal, siswa diberi kesempatan aktif secara mental, fisik dan sosial serta memberikan kesempatan kepada siswa untuk menyelidiki dan membuat jawaban serta dapat memberikan kepuasan sendiri bagi siswa.

Model pembelajaran pengajuan masalah (problem posing) merupakan salah satu pembelajaran yang menuntut para siswa untuk mengajukan soal dan memecahkan sendiri soal yang diajukannya (Rosli et al., 2014). Latar belakang masalah dapat berdasar topik yang luas, soal yang sudah dikerjakan atau informasi tertentu yang diberikan kepada siswa. Jadi dalam pembelajaran problem posing siswa dilatih untuk bertanya. Padahal, bertanya merupakan pangkal semua kreasi. Orang yang memiliki kemampuan berkreasi dikatakan memiliki sikap kreatif. Selain itu dengan pengajuan soal, siswa diberi kesempatan aktif secara mental, fisik, dan sosial serta memberikan kesempatan kepada siswa untuk menyelidiki dan membuat jawaban serta dapat memberikan kepuasan tersendiri bagi siswa jika soal yang dibuat tidak mampu diselesaikan oleh kelompok lain (Suryani et al., 2015). Model pembelajaran problem posing dengan Context-Rich Problem dapat berpengaruh terhadap kemampuan berpikir divergen siswa, karena model pembelajaran ini dapat memberikan kesempatan untuk peserta didik beperan aktif dalam mempelajari, mencari dan menemukan sendiri informasi, konsep dan membuat kesimpulan. Kemampuan pemecahan masalah harus ditunjang oleh kemampuan penalaran yakni kemampuan melihat sebab akibat (Khery \& Khaeruman, 2016).

Model pembelajaran Problem Posing dapat diterapkan dengan menyajikan Context-Rich Problem (soal-soal yang diperkarya dengan konteks), dimana Context-Rich Problem mencoba membawa siswa memasuki permasalahan yang bisa ditemui didunia nyata siswa yaitu dapat mendorong siswa menggunakan strategi pemecahan masalahan dan mempertimbangkan konteks objek nyata dimana permasalahan itu dihadirkan dan semakin dekat permasalahan tersebut dengan pengalaman keseharian siswa maka, siswa akan semakin menyukai untuk membuat hubungan-hubungan yang diperlukan dan tiba pada penafsiran yang tepat terhadap permasalahan (Khery \& Khaeruman, 2016). Jadi model pembelajaran Problem Posing dengan Context-Rich Problem mampu memancing proses mental siswa kelas eksperimen dalam memutuskan penyelesaian terbaik dalam menyelesaikan soal berdasarkan informasi yang diperoleh. Soal-soal divergen yang dapat diselesaikan oleh siswa pada kelas yang dibelajarkan dengan Problem Posing dengan Context-Rich Problem lebih teorganisir dengan baik.

Hal ini dapat disimpulkan bahwa model pembelajaran Problem Posing dengan ContextRich Problem dapat menyebabkan kemampuan berpikir divergen yang lebih baik pada siswa. Penerapan pembelajaran yang menitik beratkan pada pengembangan kemampuan berpikir divergen sangat diperlukan untuk membentuk kreativitas siswa (Rao S, 2017). Khery dan Supriani (2014) menyimpulkan bahwa Model Pembelajaran Kooperatif Tipe STAD Divergen dapat mengakibatkan kemampuan berpikir divergen siswa menjadi lebih baik. Penelitian yang dilakukan oleh (Widowati, 2008), menyimpulkan penerapan model pembelajaran Inkuiri berpengaruh terhadap kemampuan berpikir divergen siswa. Pencapaian kemampuan berpikir divergen akan bisa membantu siswa sukses dalam menjalani proses belajar sains karena cara berpikir ini sangat diperlukan saat siswa melakukan proses inkuiri saing (Khery et al., 2013; Subali \& Mariyam, 2013). 


\section{Pengaruh Model Pembelajaran Problem Posing dengan Context-Rich Problem terhadap Kemampuan Berpikir Konvergen Siswa}

Deskripsi data kemampuan berpikir konvergen siswa yang dibelajarkan dengan model pembelajaran Problem Posing dengan Context-Rich Problem, model Problem Posing saja dan model konvensional dengan Context-Rich Problem disajikan pada Tabel 6.

Tabel 6. Deskripsi Data Kemampuan Berpikir Konvergen Kelas Eksperimen I, Kelas Eksperimen II dan Kelas Kontrol

\begin{tabular}{lccc}
\hline \multicolumn{1}{c}{ Varian } & N & Mean & Std. deviation \\
\hline Kemampuan berpikir konvergen kelas eksperimen I & 26 & 34,50 & 12,84881 \\
\hline Kemampuan berpikir konvergen kelas eksperimen II & 29 & 33,25 & 12,62225 \\
\hline Kemampuan berpikir konvergen kelas control & 30 & 24,99 & 6,940319 \\
\hline
\end{tabular}

Pada Tabel 6 dapat dilihat nilai tes kemampuan berpikir konvergen siswa pada kelas eksperimen I dan eksperimen II lebih tinggi dari kelas kontrol.

Analisis normalitas data sampel menggunakan uji statistik atau melalui bantuan program bantuan program Microsoft excel 07, sehingga diperoleh hasil pada signifikan pada kelas eksperimen I, eksperimen II, dan kontrol seperti yang dipaparkan pada Tabel 7.

Tabel 7. Uji Normalitas Data Poss-test Kemampuan Berpikir Konvergen Siswa

\begin{tabular}{|c|c|c|c|}
\hline Kelas & $\begin{array}{c}\text { Chi Kuadrat } \\
\text { Tabel }\end{array}$ & $\begin{array}{c}\text { Taraf signifikan } \\
5 \%\end{array}$ & Kriteria \\
\hline Eksperimen I & 10,37 & & Terdistribusi Normal \\
\hline Eksperimen II & 9,40 & 11,070 & Terdistribusi Normal \\
\hline Kontrol & 6,82 & & Terdistribusi Normal \\
\hline
\end{tabular}

Pada Tabel 7 di atas untuk kelas eksperimen I diperoleh harga Chi Kuadrad hitung= 10,37, kelas eksperimen II diperoleh Chi Kuadrat hitung 9,40, dan kelas kontrol diperoleh Chi Kuadrat hitung 6,82. Berdasarkan tabel Chi Kuadrat dapat diketahui bahwa untuk tingkat kesalahan = $5 \%$, harga Chi Kuadrad tabel $=11,070$. Maka dari itu, Chi Kuadrat hitung lebih kecil dari Chi Kuadrat tabel. Artinya data kemampuan berpikir divergen siswa terdistribusi normal. Uji Analisis varians digunakan untuk menguji hipotesis yang berkenaan dengan perbedaan kemampuan berpikir konvergen siswa. Analisi varians yang digunakan pada penelitian ini adalah analisis varians dua jalur (two way ANOVA) dengan faktorial (2x3) dengan bantuan Microsoft excel, hasil uji hipotesis untuk kemampuan berpikir konvergen siswa dapat dilihat pada Tabel 8.

Tabel 8. Hasil Uji Hipotesis Parametris Data Kemampuan Berpikir Konvergen Siswa

\begin{tabular}{lccccc}
\hline \multicolumn{1}{c}{ Sumber variable } & Dk & $\begin{array}{c}\text { Jumlah } \\
\text { kuadrat }\end{array}$ & $\begin{array}{c}\text { Mean } \\
\text { kuadrat }\end{array}$ & Fh & Ft 5\% \\
\hline $\begin{array}{l}\text { KBK kelas Eksperimen I, } \\
\text { Eksperimen II dan kontrol }\end{array}$ & $3-1=2$ & 1631,16 & 815,58 & 0.485 & 3,26 \\
\hline $\begin{array}{l}\text { KBK berdasarkan kemampan } \\
\text { awal }\end{array}$ & $3-1=2$ & 120,52 & 60,26 & 0.035 & \\
\hline $\begin{array}{l}\text { Interaksi antara kelas dengan } \\
\text { kemampuan awal }\end{array}$ & $2 \times 2=4$ & 10191,8 & 47,92 & 1,515 & \\
\hline Kelas & $85-3 \times 3=76$ & 127797,57 & 1681,54 & & \\
\hline Total & $85-1=84$ & 139741,05 & & & \\
\hline
\end{tabular}

Dari Tabel 8 di atas diperoleh $F_{\text {hitung }}=0,485$ untuk kemampuan berpikir konvergen berdasarkan kelas, $F_{\text {hitung }}=0,035$ untuk kemampuan berpikir konvergen berdasarkan kemampuan awal, $F_{\text {hitung }}=1,515$ untuk interaksi berdasarkan kelas dan kemampuan awal dan $F_{\text {tabel }}$ untuk $\alpha=0,05$ adalah 3,26. Dapat disimpulkan bahwa $F_{\text {hitung }}<F_{\text {tabel }}$ sehingga Ho diterima dan Ha ditolak. Artinya tidak terdapat perbedaan kemampuan berpikir konvergen siswa kelas eksperimen I, kelas eksperimen II, dan kelas kontrol pada materi hidrokarbon. Dimana skor rata-rata kemampuan berpikir konvergen kelas eksperimen I 34,50; kelas eksperimen II 33,25; kelas kontrol 24,99. 
Berdasarkan deskripsi data skor rata-rata kemampuan berpikir konvergen kelas eksperimen I dan kelas eksperimen II lebih baik dari pada skor kemampuan berpikir konvergen kelas kontrol. Dimana skor rata-rata kelas eksperimen I adalah 34,50, kelas eksperimen II adalah 33,25 dan kelas kontrol adalah 24,99.

Sedangkan berdasarkan analisis data dan uji hipotesis yaitu analisis varians dua jalur (two way ANOVA) dengan factorial (2x3) dengan bantuan Microsoft excel 07 tidak terdapat perbedaan kemampuan berpikir konvergen antara kelas eksperimen I yang diberi perlakuan model pembelajaran Problem Posing dengan Context-Rich Problem, kelas eksperimen II diberi perlakuan model pembelajaran Problem Posing saja dan kelas kontrol diberi perlakuan model konvensional dengan Context-Rich Problem. Dimana hasil analisis menunjukan kelas yang kemampuan berpikir konvergen baik kelas eksperimen I, eksperimen II maupun kelas kontrol sama tingkat kemampuan berpikirnya yaitu tidak ada perbedaan.

Hal ini disebabkan karena kemampuan berpikir konvergen merupakan tingkatan kemampuan kognitif yang lebih rendah dari pada kemampuan berpikir divergen, sehingga siswa baik dikelas eksperimen I, kelas eksperimen II dan kelas kontrol bisa mencapai kemampuan yang sama baiknya. Dan dapat disimpulkan bahwa baik kelas eksperimen maupun kelas kontrol sama-sama berada pada skor kemampuan berpikir kovergen yang sama rendah dan tidak berbeda satu sama lain.

Dalam penelitian ni terdapat masalah yaitu tingkat kemampuan berpikir konvergen baik kelas eksperimen I, eksperimen II dan kelas kontrol tidak ada perbedaan. Jadi solusi yang dapat ditawarkan dalam penelitan ini adalah tingkat kesulitan soal konvergen, soal-soal dan metode penilaian yang dibuat agar lebih bervariasi, lebih banyak, lebih sulit agar dapat meningkatkan pemikirannya. Sehingga siswa harus benar-benar fokus pada sebuah jawaban benar agar dapat menemukan penyelesaian permasalahan. Dimana pemikir konvergen memiliki skor yang lebih tinggi dalam permasalahan-permasalahan yang menghendaki sebuah penyelesaian yang secara umum dapat diterima.

Perlu menyediakan media dalam pembelajaran Problem Posing dengan Context-Rich Problem agar pembelajaran lebih efisien dan ketercapaian kemampuan berpikir konvergen bisa lebih tinggi. Berpikir konvergen sangat diperlukan untuk membentuk karakter berpikir kritis siswa (Khery \& Supriani, 2014). Kemampuan berpikir konvergen mencakup ekmampuan menganalisis dan mengambil keputusan yang tepat dalam pemecahan permasalahan sains. Probel Posing sangat tepat untuk diterapkan dalam rangka melatihkan kemampuan analisis siswa (Suryani et al., 2015).

\section{KESIMPULAN}

Berdasarkan analisis data hasil penelitian dan pembahasan dapat disimpulkan bahwa ada pengaruh penggunaan model pembelajaran Problem Posing dengan Context-Rich Problem terhadap kemampuan berpikir divergen siswa. Hasil analisis uji varian dua jalur (two way ANOVA) KBD menunjukan nilai signifikan yaitu $F_{h}>F_{t}(4,128>3,26)$. Nilai rata-rata kelas eksperimen I $(55,38)$, kelas eksperimen II $(40,91)$ dan kelas kontrol $(42,23)$. Tidak ada pengaruh penggunaan model pembelajaran Problem Posing dengan Context-Rich Problem terhadap kemampuan berpikir konvergen siswa. Hasil analisis uji varian dua jalur (two way ANOVA) KBK menunjukan nilai signifikan yaitu $\mathrm{F}_{\mathrm{h}}<\mathrm{F}_{\mathrm{t}}(0,449<3,26)$. Nilai rata-rata kelas eksperimen I $(34,50)$, kelas eksperimen II $(33,25)$, kelas kontrol $(24,99)$.

\section{REKOMENDASI}

Masih diperlukan studi tentang penggunaan inovasi pembelajaran untuk meningkatkan kemampuan berpikir konvergen siswa. Kemampuan berpikir konvergen sangat dibutuhkan terutama saat siswa dituntut harus menghasilkan keputusan terbaik dan paling meyakinkan dalam pemecahan masalah-masalah sains.

\section{UCAPAN TERIMAKASIH}

Terima kasih yang sebesar-besarnya kepada LPPM UNDIKMA yang telah mendanai penelitian ini.

DAFTAR PUSTAKA

Arikunto, S. (2013). Prosedur Penelitian. PT Rineka Cipta. 
Eristya, A. M., \& Aznam, N. (2019). Natural Science Learning with Modified Free Inquiry to Develop Students' Creative Thinking Skills. Journal of Physics: Conference Series, 1233(1). https://doi.org/10.1088/1742-6596/1233/1/012107

Hidayatulloh, R., Suyono, S., \& Azizah, U. (2020). Development of STEM-Based Chemistry Textbooks to Improve Students' Problem Solving Skills. Jurnal Penelitian Dan Pengkajian IImu Pendidikan: E-Saintika, 4(3), 308-318. https://doi.org/10.36312/esaintika.v4i3.306

Indrayani, P. (2013). Analisis Pemahaman Makroskopik, Mikroskopik, dan Simbolik Titrasi Asam-Basa Siswa Kelas XI IPA SMA serta Upaya Perbaikannya dengan Pendekatan Mikroskopik. Jurnal Pendidikan Sains, 1(2), 109-120.

Khery, Y., \& Khaeruman. (2016). Pengaruh Context-Rich Problems Berbentuk Multimedia Interaktif terhadap Keterampilan Proses Sains, Sikap IImiah, dan Pemahaman Konsep. Prisma Sains: Jurnal Pengkajian IImu Dan Pembelajaran Matematika Dan IPA IKIP Mataram, 4(2), 83-93.

Khery, Y., Subandi, S., \& Ibnu, S. (2013). Metakognitif, Proses Sains, Dan Kemampuan Kognitif Mahasiswa Divergen Dan Konvergen Dalam Pbl. Prisma Sains: Jurnal Pengkajian IImu Dan Pembelajaran Matematika Dan IPA IKIP Mataram, 1(1), 37. https://doi.org/10.33394/j-ps.v1i1.517

Khery, Y., \& Supriani, D. (2014). Pengaruh Strategi Pengembangan Keahlian Berpikir Divergen Dengan STAD Terhadap Karakter Berpikir Divergen Konvergen dan Kemampuan Berpikir Siswa. Hydrogen: Jurnal Kependidikan Kimia, 2(1), 153. https://doi.org/10.33394/hjkk.v2i1.643

Rao S, A. (2017). Research Article. SciFed Dental \& Oral Research Journal, 1(4), 1-11. https://doi.org/10.23959/sfdorj-1000021

Rosli, R., Capraro, M. M., \& Capraro, R. M. (2014). The effects of problem posing on student mathematical learning: A meta-analysis. International Education Studies, 7(13), 227241. https://doi.org/10.5539/ies.v7n13p227

Subali, B., \& Mariyam, S. (2013). Pengembangan Kreativitas Keterampilan Proses Sains Dalam Aspek Kehidupan Organisme Pada Mata Pelajaran Ipa Sd. Jurnal Cakrawala Pendidikan, 32(3), 365-381. https://doi.org/10.21831/cp.v3i3.1625

Sugiyono. (2010). Metode Penelitian Kuantitatif, Kualitatif, dan R\&D. CV Alfabeta.

Suryani, L., Saputro, A., \& Martini, K. (2015). Implementasi Model Pembelajaran Problem Posing Dilengkapi Lks Untuk Meningkatkan Kemampuan Analisis Dan Prestasi Belajar Materi Konsep Mol Siswa Kelas X Sma N 8 Surakarta Tahun Pelajaran 2013/2014. Jurnal Pendidikan Kimia Universitas Sebelas Maret, 4(4), 186-192.

Suryati, S., Khery, Y., \& Dewi, C. A. (2017). Development Strategy of Inquiry Based Mobile Learning on General Chemistry Development Strategy of Inquiry Based Mobile Learning on General Chemistry Classroom. January. https://doi.org/10.5220/0007305804390443

Widowati, A. (2008). Impoving the Divergent Thinking Skill Using the Modified free Inquiry Approach To Teaching Science. Jurnal Penelitian Dan Evaluasi Pendidikan, 1, 118127. 